\title{
Consumer habits and preferences in the renewable energy market
}

\author{
Péter Balogh ${ }^{1}$, Attila Bai ${ }^{1}$, Károly Pető ${ }^{1}$, Zoltán Szakály ${ }^{1}$ \\ ${ }^{1}$ Faculty of Economics and Business, University of Debrecen, Hungary
}

\begin{abstract}
Renewable energy sources can have considerable potential for residential cost reduction, sustainable energy consumption and local income production.
\end{abstract}

Our aim is to analyse the knowledge of Hungarian consumers about renewable energy sources, their willingness to apply them and the socio-demographic factors concerning these issues. To achieve the research objectives, a nationally representative survey with 1000 people was launched in April 2019 in Hungary.

Based on the results of the questionnaire, it was concluded that the information people have is below the average in the case of every examined renewable energy source, which is especially true for biomass-based energy sources. Convenience is almost as important as environment friendliness. An excessively high rate of respondents (34 and $27 \%$ ) is interested in solar panels and solar collectors, while $32 \%$ of them are unwilling to use these energy sources.

It would be justified to extend this consumer research in the future for more countries. The authors wish to clarify how the differences in location, income status, residential segment and values influence the spread of these energy sources in the EU and what tools could promote their use in the future.

Keywords: energy, consumption, attitude, segmentation, knowledge 


\section{Introduction}

World energy consumption was about 567-578 EJ in 2017, which is still on the increase - in 2017 by $2.2 \%$, and by $1.7 \%$ on average yearly since 2006 (BP, 2018, IEA, 2018). Within this, the consumption of the residential segment plays a significant role both in the EU (42\%) and in Hungary (35\%) as well (Eurostat, 2019). The Hungarian population spend $12.8 \%$ (35 EUR/capita/month) of their income on energy sources, and this rate is even higher in the case of pensioners, singles and lower income groups (KSH, 2019). At the same time, the rate of renewables in the energy mix has stagnated for years worldwide (14\%), it is a bit higher in the EU and in Hungary than the world average (18-18\%, IEA, 2018). Thus, renewable energy sources can have considerable potential for residential cost reduction, sustainable energy consumption and local income production.

Our aim is to analyse the knowledge of Hungarian consumers about renewable energy sources, their willingness to apply them and the related socio-demographic factors. To achieve the research objectives, a nationally representative survey with 1000 people was launched in April 2019 in Hungary.

\section{Literature review}

In their case study Assefa and Frostelld (2007) assessed the social acceptance of energy technologies with regard to the knowledge and fear associated with them. The findings of the study indicated that social acceptance was a crucial factor in the future spread of these technologies, whereas the lack of reliable knowledge could have extremely adverse effects on acceptance.

Prior to the current study, several surveys were already conducted in Hungary, aiming at assessing the knowledge of different social segments concerning different renewable energy technologies.

According to a questionnaire-based survey on energy recovery from by-products in 1996 by Bai (1998), with the polarization of the society the price of energy is becoming a vital factor for an increasing number of people and this may outweigh reasons of convenience. Biobriquette was found to arouse the most interest among the participants of the survey. 
Tóth (2013) carried out representative research in one of the most underdeveloped regions of Hungary (the valley of River Hernád), in which he concluded that people were primarily motivated by the possibility of reducing costs, however their lack of information hindered the selection of the appropriate energy source. Current communication channels provided the population with little and often false information. The knowledge of different age groups differed to a great extent and owing to internet usage younger people showed more awareness. Current Geography textbooks in elementary and secondary schools contained very little, disproportionately distributed and outdated information about renewable energy resources (Pajtkóné Tari et al. 2011). Only 10-15\% of those surveyed in the area were found to be willing to accept the implementation of large-scale renewable investment projects in their own settlements.

Jobbágy conducted research among Hungarian motorists on biofuels. According to his findings, respondents typically reflected a positive attitude to biofuels, especially in terms of environmental protection, and their knowledge did not fall behind the European or North American average. The main source of their knowledge was the Internet, which is welcome on the one hand, since that is the quickest possible way to acquire the latest, updated information. On the other hand, however, it also poses risks, as false information is equally easily accessible and the source of information is often difficult to verify (Jobbágy, 2013).

\section{Methodology}

In order to achieve the objectives of the research a nationally representative questionnaire-based survey with 1000 people was launched in April, 2019 in Hungary. During sampling in the given regions representativeness was per se provided, thus its structure was fully compliant with the quota established previously by the Hungarian Central Statistical Office (quota sampling).

The settlements in the given regions and the addresses in the settlements were selected by drawing lots (simple random sampling). The so-called random walking principle was applied in the designated settlements, which provided complete randomness in the selection of suitable respondents. As a second step the person for the interview from among the members of the households visited was selected by using the so-called „birthday key”. The principle of the method is that the person, 
whose birthday comes closest to the day of the interview from among people of the appropriate age (18 years of age or above) must be chosen for the interview.

As random sampling did not grant representativeness between the sample and the population, the sample had to be corrected by using multidimensional weightings according to gender and age. After correction the sample represents the composition of population based on four factors (region, type of settlement, gender and age).

For the evaluation of the database, besides statistical indicators (mean, standard deviation, frequency, median, mode), hypothesis tests were also carried out. During this procedure, a test of independence (Chi-Square, contingency coefficient) was used to determine the relationship between the different socio-demographic categories and the most important economic and marketing factors influencing the future spread of renewable energy sources. The level of significance used by us was $5 \%$.

\section{Results and Recommendations}

Based on the results of the questionnaire, it was concluded that the information people had was below the average in the case of every examined renewable energy source, which was especially true for biomass-based energy sources. Convenience is almost as important as environment friendliness.

The findings of our study suggest that the differences with regard to the basic level knowledge about renewable energy resources can be summarized as follows:

- Differences by gender no difference: solar, wind, hydropower there is a significant difference in favour of men: geothermal energy, heat pumps, biobriquette, wood pellet, biogas, biodiesel, bioethanol

- Qualifications play a significant role in the awareness of every examined energy source, people with elementary schooling are significantly uninformed as compared to others.

- People living in the capital have heard less about wind energy and more about geothermal energy, biobriquette, wood pellet, biodiesel, and bioethanol than those living in other types of settlements. Solar- and hydroenergy have been found to be at the same awareness level in different types of settlements. 
- Based on our research environment-consciousness does not make a difference as regards awareness.

- People with higher income are considerably more aware of energy sources available at higher prices (geothermal energy, heat pumps, wood pellet, biogas, biodiesel, bioethanol).

An excessively high rate of respondents (34 and 27\%) is interested in solar panels and solar collectors, $32 \%$ of them are unwilling to use these energy sources.

Overall, when buying energy, people make their decisions based mostly on cheap running costs and convenience factors, rather than on environmentally friendly considerations. For $54 \%$ of all respondents environment protection proved to be the least important factor to consider.

It would be justified to extend this consumer research in the future for more countries. The authors wish to clarify how the differences in location, income status, residential segment and values influence the spread of these energy sources in the EU and what tools could promote their use in the future.

\section{Acknowledgment}

This research was supported by EFOP-3.6.1-16-2016-00022 „Debrecen Venture Catapult Program".

The research was financed by the Higher Education Institutional Excellence Programme (20428-3/2018/FEKUTSTRAT) of the Ministry of Human Capacities in Hungary, within the framework of the 4. thematic programme of the University of Debrecen.

\section{References}

1. Assefa, G., Frostell B. (2007): Social sustainability and social acceptance in technology assessment: a case study of energy technologies, Technol. Soc. 29 pp. 63-78.

2. A. Bai, E. Durkó, K. Tar, J. B. Tóth, I. Lázár, L. Kapocska, A. Kircsi, B. Bartók, R. Vass, J. Pénzes, T. Tóth: Social and economic possibilities for the energy utilization of fitomass in the valley of the river Hernád Renewable Energy, RENEWABLE ENERGY, Volume 85, ISSN: 09601481, doi:10.1016/j.renene.2015.06.069 
3. Bai A.: A mezőgazdasági és élelmiszeripari melléktermékek energetikai hasznosításának gazdasági összefüggései. Doktori (Ph. D.) értekezés. Debrecen, 1998., pp. 1-168.

4. BP (British Petrol, 2018): Statistical Review of World Energy. 67th edition, pp. $1-52$

5. Eurostat (2019): https://ec.europa.eu/eurostat/statisticsexplained/index.php/Renewable_energy_statistics

6. International Energy Agency (IEA, 2018): Key World Energy Statistics. www.iea. org/statistics, pp. 1-51

7. Jobbágy, P. (2013): A hazai biodízel-ágazat komplex elemzése. Doktori (Ph.D.) értekezés. Ihrig Károly Gazdálkodás- és Szervezéstudományok Doktori Iskola. pp. 1-159.

8. KSH (Hungarian Central Statistic Agency, 2019). http://www.ksh.hu/thm/3/indi3 1 2.html

9. Pajtkóné Tari I.-Kiss B.-Ruszkai Cs.-Mika J. (2011): A megújuló energiák internetes forrásainak felhasználása a földrajzoktatásban. - In. SZABÓ V.FAZEKAS I. (szerk.): Környezettudatos energiatermelés és -felhasználás. Meridián Alapítvány, Debrecen. pp. 264-269.

10. Tóth T. (2013) A megújuló energiaforrások társadalmi háttérvizsgálata a Hernád-völgy településein, különös tekintettel a dendromassza-alapú közösségi hőenergia-termelésre értekezés. Doktori (Ph.D.) értekezés. Földtudományok Doktori Iskola. pp. 1-159. 